\title{
Un-Silencing the Past: A Juxtaposition of Personal and Political in Elif Shafak’s Novel, The Bastard of Istanbul
}

\author{
Tajamul Islam \\ Ph.D. English \\ Maulana Azad National Urdu University \\ Hyderabad, India \\ itajamul473@gmail.com
}

Abstract

This paper explores the thematic aspect of bastard and the alternative spaces present in the novel to show how Armenian genocide is addressed and unsilenced from the censorship of the State. The juxtaposition of the Armenian issue with the tribulations of 'Kazanci' family is argued as a metaphorical and personalised account of Armenian genocide. Such an engagement with the past has been made possible by bringing political and personal together in the form of a family in Istanbul and a family in America; one belonging to a Muslim majority and the other belonging to an Armenian religious minority.

Keywords: Censorship, Alternative Spaces, Genocide

Introduction

Elif Shafak is a reputed contemporary Turkish writer who attracted controversy over the political views espoused by one of the characters in The Bastard of Istanbul. She was put on trial for denigrating "Turkishness" under Turkish panel code due to, "the words that some of the Armenian characters spoke in the novel" (Acknowledgement, The Bastard of Istanbul, 359). Orhan Pamuk, another novelist from Turkey was also charged under the same panel code when he mentioned Armenian genocide in one of his interviews. 
In the context of the sensitivity of the issue in Turkey, and the successive govt's attempt to censor any discussion on it, this paper explores how Elif Shafak creates alternative spaces to engage with this question within the framework of art, and also juxtaposes personal and political to create a personalised account of Armenian genocide in order to put this historical wrong in proper perspective.

Elif Shafak writes in a separate section entitled "Dreaming in English" in her novel The Bastardof Istanbul:

The Bastard of Istanbul is a novel that concentrates on an Armenian and a Turkish family and the unspoken atrocities of the past. Had I written this in Turkish, it might have been a different book...but writing the story in English freed me from the cultural and psychological constraints I internalise unconsciously in Turkish (363). The bastard child evokes significations of a haunting past, an unacknowledged history, identity crisis, rootlessness and more significantly a reality that no one wants to face. Turkish noble laureate, Orhan Pamuk also uses bastard theme in his latest novel, The RedHaired Woman (2018) in which an unacknowledged past continues to haunt the protagonist throughout his life despite being prosperous and a well-known real estate businessman. The stark resonance can also be found in Sam Shepherd's play The Buried Child (2006), and also in Nadine Gordimer's The Conservationist (2017) in which the burden of past weighs heavily on the lives of the characters indicating a deeply rooted historical problem.

Before the novel under discussion is explored, a brief overview of the history of Armenian genocide warrants attention to put it in a proper historical perspective. The massacre of Armenians (Christian minority in OE) in 1915, continues to sever the relationship between Turks and Armenians. At the time of the First World War (1914-18) when Ottoman Empire was collapsing slowly, it was facing its worst existential crisis from three significant places: Mesopotamia, Dardanelles, and Caucasus. Armenians were accused 
of supporting Russians in their war against Ottoman Empire. Eugene Rogan, a historian of repute writes, "The divided loyalties of some Armenians had tarred all Armenians in the eyes of many Turks. The Young Turk leadership began to contemplate permanent solutions to the "Armenian problem" (The Fall of Ottomans 136). He further writes about the demography of Armenians who were a minority in every province of the Ottoman Empire at that time: Armenians were concentrated in three areas of particular sensitivity during the First World War. Istanbul threatened with imminent Allied invasion, was home to the largest concentration. In Cilicia, overlooking the gulf of Alexandretta, the Ottomans suspected the Armenian community of making common cause with Allied fleet. In the Caucasus, a minority of Armenian activists compromised the standing of the community as a whole when they allied themselves with Russia against the Ottoman Empire...because some Armenians had hoped to create an independent homeland in Ottoman territory with Allied support (164).

In February 1915, Ottomans started deporting entire Armenian population to Adana for the fear of an imminent attack from Allied forces and their support to them. The entire political and cultural leadership of Armenians was decapitated and mass arrests also started. Two-pronged strategy was adopted to get rid of Armenians which was to deport them and then kill them through mercenaries along the way, what Armenian's call "death marches" and in the process around one million people perished. Eugene Rogan writes:

The debate persists into the twenty-first century as to whether the mass murder of Armenians between 1915 and 1918 was an unintentional consequence of war or a deliberate policy of extermination. But even those who deny Armenian genocide acknowledge that between 600,000 and 850.000 civilians perished as a result of war time measures $(183)$ 
The persistent denial of genocide and censorship by Turkish government continues to mar the relationship between these two communities. Even at present, anyone who mentions this genocide is punished under Turkish penal code. Asiya, a character in The Bastard of Istanbul writes in response to Armenian massacre that Turkish national history is based on censorship.

\section{Bastard of Istanbul in Context}

In an interview with New Perspective Quarterly, 2005 entitled "Linguistic Cleansing” Elif Shafak tells that Turks have lost curiosity for the past and it is treated like a bygone thing. She argues that "Anything that might have happened before that is of no interest to us...For instance, we cannot speak about 1915, the year of the Armenian massacre, and many people don't know anything about it and they're not interested in it" (22). She further tells that, "I do not only try to unearth the stories that have been buried under the ground by the Kemalists. I also try to unearth the words that have been kicked out of Turkish language. I bring them back." (22). In other words, she not only brings past back through her stories but through her style as well. By employing Ottoman syntax, she fills the void left by "linguistic cleansing" done by the policies of Turkish republic.

Literature is considered as a tool that fills gaps, brings to fore silenced histories, and makes people face their inconvenient past through the sheer sagacity of its art. Elif Shafak's The Bastard of Istanbul strives to bring the inconvenient past to surface through diverse characters.

The Bastard of Istanbul revolves around two families: Armenian-American Tchakhmakhcians living in San Francisco and Turkish Kanznci's in Istanbul. The two families are connected by a common thread of rootlessness, felt by Asiya Kazanci on one hand, and Armanoush Tchakhmakhchian on the other hand. Asiya, the bastard, is inclined towards nihilism and suffers existential crisis due to her absent father. She becomes a devout 
reader of existential philosophers and listens to Johnny Cash's depressing songs. She is the daughter of Zaliha who was raped by her own brother, Mustafa. Mustafa flees to America to exterminate his contaminated past from his life and become a different person. All these characters are feeling the pangs of their past despite their attempt to erase it from their memory. Armanoush in the same way is struggling with her past which remains untraceable to her as an Armenian except in the form of a historical wound on her community. The bastard child is a metaphorical representation of Turkey's tension between the Ottoman past and its republican present. Elena Furlanetto argues in this regard,

The unspeakable event that triggered this form of ostracism is the rape of Zeliha by her own brother Mustafa. This deed is never addressed in Asya's household for fear of the consequences and, as a result, Asiya ignores who her father is. Thus, Asya's ignorance about her past, and her aunts' compliance with it, find a direct correspondence in the rupture between Turkey's republican present and its Ottoman past, suppressed by Kemalism for the fear it could threaten Turkey's self-perception as a Westernized democracy (84).

Armanoush is the daughter of Basram Chakhmakhchian, an Armenian by birth and Rose, his mother, an American by birth. The marriage ends up in divorce, and she later marries a Turkish man Mustafa, the brother of Zaliha. Armanoush visits Istanbul in search of her roots without the consent of her parents. Her visit to Kazanci family in Istanbul brings the political history as well as the family's past to surface. The suspense ends when we get to know that Asiya is the bastard child of her own uncle Mustafa who had fled to San Francisco to avoid a family curse that resulted in the deaths of all the male members of their family. Simultaneously, we also get to know that Armanoush's grandmother, Sushan was an Armenian who had fled when Armenian genocide was going on. However, the plot is more 
than simple. The political history of the country and the relation between these two families is intricately linked.

\section{Un-silencing the Past through Alternative Spaces}

Since the past has been silenced through procrustean reforms rooted in contemporary Turkish history and politics and also by penalising any discussion on the deportation and the genocide of Armenians during the First World War, Elif Shafak unravels the past indirectly in the novel through alternative spaces which is indicative of censorship imposed by the State and also symbolises the breakdown of a direct communication between these two communities for decades. Owing to state repression and censorship, Armenian massacre is brought to surface through such alternative spaces in the novel. These spaces critique and put in perspective the historical wrong, and also subverts "mainstream" thought process aimed at streamlining a heterogeneous community into a single state sponsored "subjects". In the novels of Pamuk and Elif Shafak these spaces have a vital importance both in terms of form as well as the content, eliciting direct as well as metaphorical responses to the most contentious political issue of Armenians in Turkey. Elena Furlanetto also undertakes the examination of such imaginary spaces while comparing Orhan Pamuk's The Black Book and Elif Shafak's The Bastard of Istanbul. She considers the representation of the "over-ground" and "underground" spaces in both these novels as a metaphor for the Turkish division. One founded on historical amnesia of the past and another one a vibrant space where heated debates are conducted and narratives contested. Such spaces are represented in The Black Book in the underground city which Bedi Usta has preserved with the richness of the past civilizations, and another over-ground city which has taken recourse to historical amnesia and the erasure of its past. 
The alternative spaces where discussion on the censored issue takes place are Cafe Kundera, Cafe Constantinopolis, djinni of Clairvoyant Banu, and all-female family of Kazanci's; none of these are mainstream, public or popular spaces. Kazanci family lacks a patriarch. The last one dies at the age of 40 after raping his sister. Banu has a jinni at her command that extracts information for her and is witness to many untoward incidents in people's lives. Cafe Kundera is based in Istanbul where urban intellectuals, nihilists, pessimists, alcoholics, poets, movie- makers and anarchists hang around. Cafe Kundera, we are told is a self-regulating organism, "where individual differences were displayed but could never take over" (81). These are the people who feel cornered by the polarisation created by traditionalists on the one hand and modernists on the other. They call themselves an extinct minority without any human rights protection. Dipsomaniac Cartoonist sums up the essence of Kundera goers who flee the polarised society they cannot align with:

Boredom is the summary of our lives...because we cannot abandon this rabbit hole for fear of a traumatic encounter with our own culture...Western politicians presume there is a cultural gap between Eastern civilization and Western civilisation. If it were that simple! The real civilizational gap is between the Turks and the Turks" (81). He outlines his existential philosophy by calling it Kitsch by saying that, "our existence is kitsch -a beautiful lie, which helps us to defy the reality of death and mortality" (81). Elena Furlanetto argues in her book, "Café Kundera emerges as a site where the manipulation of history operated by Turkish nationalism and, at a smaller scale, by single individuals and families is exposed and challenged" (84).

Cafe Constantinople's and djinni of Banu are other spaces where the conversation on Armenian genocide takes place. These spaces also represent the disruption of a normal conversation that cannot take place in public. Even in the family, the history of the tribulations of Sushan can only be narrated by a jinni of Banu and not by any normal human 
being. Cafe Constantinople's is an online chatroom where diasporic Armenian community get together and talk. Jinni is a supernatural force at the command of a clairvoyant named Banu who unveils the extermination of Armenian community from the country. All these spaces constitute what Michel Foucault would call "heterotopias" or as counter-sites. In Foucault's own words:

there are also, probably in every culture, in every civilization, real places - places that do exist and that are formed in the very founding of society - which are something like counter-sites, a kind of effectively enacted utopia in which the real sites, all the other real sites that can be found within the culture, are simultaneously represented, contested, and inverted. Places of this kind are outside of all places, even though it may be possible to indicate their location in reality. Because these places are absolutely different from all the sites that they reflect and speak about, I shall call them, by way of contrast to utopias, heterotopias. (Foucault, "Of Other Spaces" 3). 64 It is through these heterotopias that a counter narrative is created to discuss and critique the amnesia amnesiaofTurkswhilesimultaneou slybreakingthestatecensorshiponthesubject.Let'snowfocuso nthesespacestohighlightwhatkindofengagementismadepossiblethroughthemandhowpersonala ndthepoliticalarejuxtaposedinthenovel.

\section{Juxtaposing Personal and the Political}

Elif Shafak argues that Turks have lost the curiosity for the past. This issue is amply addressed in the novel with respect to both Armenians and Turks. The narrator tells us that Turks and Armenians live in two different time frames,

"for the Armenians time was a cycle in which the past incarnated in the present and the present birthed the future. For the Turks time was a multi hyphenated line, where 
the past ended at some distinct point and present started anew from scratch, and there was nothing but rupture in between" (BOI 165).

This throws light on a critical issue of the relevance of the past for the subjugated and the oppressed people. Past holds a significant position in the mind of a persecuted community. One member at Cafe Constantinopolis responds to Asiya, "The oppressor has no use for the past. The oppressed has nothing but the past" (261). When Armanoush discusses the past of her community with Turkish Kazanci family, she complains in front of her friends that, "The women in the house listened to my family's history with sincere interest and sorrow but that is as far as they could get. The past is another country for the Turks" (183). The luxury of forgetting past cannot be afforded by a persecuted community because that is from where they draw their strength to resist and find meaning in their lives.

Asiya's hollowness in life, and the past of Armenians have been juxtaposed in the novel to impress on the issue of the immutability of the past. Just as a fatherless child, Asiya cannot cope up with her life, in a similar way past is far too important for a community that has been denied access to it. The mixed feeling of Asiya towards the past conveys effectively the trauma that past bears on the present of Armenians. Here is how the personal of Asiya metaphorically represents the political of Armenians. She tells Armanoush, "I have conflicting voices inside me on this issue...All I know about my past is something wasn't right, and I cannot attain that information. There is no continuity in time. You can't feel attached to ancestors if you can't even trace your own father" (Italics added BOI 180). In other words, Asiya's nihilism emerges as a direct offshoot of her absent father. No matter how much she tries to distance herself from the past, it continues to haunt her. In a conversation with her fellows at Cafe Constantinopolis, one of Armanoush's friends, Baron Bhagdassarian, makes an incisive critique of Turkish denial of Armenian genocide in detail: 
All we Armenian's ask for is the recognition of our loss and pain, which is the most fundamental requirement for genuine human relationships to flourish. This is what we say to Turks: Look we have been mourning for almost a century now, because we lost our loved ones, we were driven out of our homes, banished from our land; we were butchered like animals and treated like sheep...even the pain inflicted on our grandparents is not as agonizing as the systematic denial that followed (180).

In the conversation that ensues at Cafe Constantinopolis, she is told to apologize for her ancestor's brutality. She first recognizes the wounds inflicted on this community but falls short of apologizing. She is told to apologize on behalf of the state to which she responds, "My State? I have got nothing to do with the state". She further writes to them, "You want me to apologize for something I personally had nothing to do with?” (262) to which one of the members responds, "we are all born into continuity in time and the past continues to live within the present. We come from a family line, a culture, a nation. Are you gonna say let bygones be bygones?" (262). It takes her a little while to understand the importance of the statement when she feels in the heart of her hearts that the past does live within the present. She provides the most acute analysis of her personal and political analogy in her final comments on the subject. She writes, while admitting the continuity of time and empathising with Armenians:

Perhaps it is exactly my being without a past that will eventually help me to sympathise with your attachment to history. I can recognize the significance of continuity in human memory. I can do that...and I do apologize for all the sufferings my ancestors have caused your ancestors (263).

Asya's thought metamorphosises finally, and culminates in the acceptance of her own past and the genocide of Armenians and as a result she tenders her apology to Armenians. This is the most astute way of juxtaposing personal and the political, the past and the present, 
the memory and the wound. This issue however is not simplistically resolved in the novel. Elif Shafak is very cautious of such discussion stooping to generalisation and oversimplification. She problematizes the binary of the subject and the State by bringing dissident voices to surface who are themselves in the surveillance of the State for deviating from State-centric, nation- statist perspective of history and politics. One such character in the novel is Dispomanic Cartoonist who had sketched the Prime minister in wolves clothing for which he was put on trial.

The difference between men reacting to Armenian massacre and women reacting to it is explicitly highlighted in the novel. Women listen to Armanoush's stories with sincerity and sorrow while as men are reactionary and defend it from the perspective of nationalism. The alternative spaces provide a vibrant understanding of the Armenian past and its effect on the present of diasporic community. The only space that is directly linked with this communication is an all-female family space and a Closeted-Gay columnist. In other words, it is heterosexual, aggressive masculine and Secular state that doesn't recognize the genocide of Armenians.

The significance of the past especially for those who are persecuted and carry the historical wound in their memory can be thoroughly understood from Mustafa Kazanci who cannot afford the prolonged denial of his past. Juxtaposing the fate of Kazanci family with Armenian problem is a metaphorical way of explaining why we must come to terms with our past and why past cannot be easily done away with.

Mustafa Kazanci tried to stay in persistent denial and engage in amnesia over his past but it proved way too weighty for him to contain. The "twin current", which he was accompanying, tore his inner self between who he actually was and what his wife thought him to be. At times, the narrator tells us, "He had been satisfied impersonating a man without past, a man with a cultivated denial...there was somewhere inside his brain a gate that 
wouldn't close no matter what; some memories always escaped" (TBOI 334). He had thought that the past was detrimental to his existence, "For me to exist, the past had to be erased" (337). However, when he returns to Istanbul, he had to face his past, and his memories. The narrator tells us, "Now, he felt like the past was returning. And for it to exist, he had to be erased" (337). Finally, Mustafa dies at the age of 40 weighed down by his past when he comes to know that Asiya is none other than his own daughter born out of his "forced masculinity" - the rape. In other words, it is a metaphorical argument that in order to erase a historical wrong, the signs and symbols that remind it must cease to exist and be abolished.

Neither Asiya nor Mustafa could afford to forget their past despite their perpetual denial. They had to ultimately come to terms with it to assuage the inner conflict that was gnawing at them continuously. Therefore, arguing let bygones be bygones to a persecuted community and not coming to terms with the source of an unhealed historical wound, coexistence between two communities is just a shallow expectation.

As mentioned earlier by Asiya herself that Turkish national history is based on censorship. One more argument that surfaces after the analysis of the novel is that Turkish deliberate amnesia and denial of Armenian genocide is an offshoot of a heterosexual, toxic masculine and secular base of the country. One of the mouth pieces of Turkish denial of this case is Non-nationalist Scenarist of Ultranationalist Movies, a member at Cafe Kundera who calls Armenian genocide, a collective hysteria and likens it to the infamous Salem Witch Trials. The irony within the name of this man in the novel is reflective of his character. $\mathrm{He}$ claims he doesn't believe in the "crap" of nationalism and yet reproduces a series of movies on Turks macho and aggressive national heroes to earn millions. This hypocrisy is called out by Asiya who tells him,

Let me tell you what collective hysteria is. All those scripts you have penned thus far, the whole series of Timur the lionheart — the muscular herculean Turk running from 
one adventure to another against the idiot byzantine. That's what I call hysteria. And once you make it into a TV show and make millions internalise your awful message, it becomes collective hysteria (211).

The Closeted-Gay Columnist also responds, "Yes, those entire vulgarly macho Turkish hero's you created to ridicule the effeminacy of the enemy are the sins of authoritarianism" (211).

\section{Conclusion}

Elif Shafak by juxtaposing the tribulations of the Kazanci family with Armenian genocide creates a personalised account of a silenced historical and political story to make it relatable to the public in an effective way. Today, as Turkey wants to reclaim its Ottoman past in its culture and politics; the Armenian question becomes more significant and relevant. For the most part of its contemporary history, Turkey had sought to delink itself from the cultural, linguistic and historical roots of Ottoman past as a replacement for the Westernization and secularization of the country. The past proved way too weighty to be out rightly discarded. In the novel neither Asiya nor Mustafa, neither Armanoush nor other Armenians could easily discard their past as it continued to live in their present signifying a shared conclusion on a historical wrong and why the past needs to be encountered and addressed properly for better social and political cohesion. 


\section{Works Cited}

Foucault, Michel. "Of Other Spaces: Utopias and Heterotopias"

Shafak, Alif. The Bastard of Istanbul. Penguin Essentials, 2019.

Shephard, Sam. Buried Child. Vintage Books, 2006.

Rogan, Eugene. The Fall of the Ottomans: The Great War in the Middle East, 1914- 1920. United Kingdom, Penguin Books Limited, 2015.

Pamuk, Orhan. The Red-Haired Woman. India, Penguin Random House India Private Limited, 2018.

SHAFAK, ELIF. “Linguistic Cleansing.” New Perspectives Quarterly, no. 3, Wiley, June 2005, pp. 19-25.https://onlinelibrary.wiley.com/doi/epdf/10.1111/j.15405842.2005.741_1.x

SHAFAK, ELIF. “Turks Look Forward with Amnesia.” New Perspective Quarterly,Wiley 2, 2015, pp. 29-32. https://doi.org/10.1111/j.1540-5842.2007.00878.x 